\title{
Erratum to: A multi-agent cooperative reinforcement learning model using a hierarchy of consultants, tutors and workers
}

Bilal H. Abed-alguni ${ }^{1}$. Stephan K. Chalup ${ }^{1}$.

Frans A. Henskens ${ }^{1}$. David J. Paul ${ }^{2}$

Published online: 28 July 2015

(C) The Author(s) 2015. This article is published with open access at Springerlink.com

\section{Erratum to: Vietnam J Comput Sci}

\section{DOI 10.1007/s40595-015-0045-x}

The family name of the first author was misspelled in the original article.

The correct family name is given above.

Open Access This article is distributed under the terms of the Creative Commons Attribution 4.0 International License (http://creativecomm ons.org/licenses/by/4.0/), which permits unrestricted use, distribution, and reproduction in any medium, provided you give appropriate credit to the original author(s) and the source, provide a link to the Creative Commons license, and indicate if changes were made.

The online version of the original article can be found under doi:10.1007/s40595-015-0045-x.

Bilal H. Abed-alguni

bilal.abedalguni@uon.edu.au

Stephan K. Chalup

Stephan.Chalup@newcastle.edu.au

Frans A. Henskens

Frans.Henskens@newcastle.edu.au

David J. Paul

David.Paul@une.edu.au

1 School of Electrical Engineering and Computer Science, University of Newcastle, Callaghan, NSW 2308, Australia

2 School of Science and Technology, University of New England, Armidale, NSW 2351, Australia 